\title{
Climate Analogue Mapping for Coffee Production in Ethiopia
}

\author{
Girma Abebe Kalifa Nasiro Hawi Mohammed* \\ Department of Horticulture and Plant Sciences, College of Agriculture and Veterinary Medicine, Jimma \\ University, P.O. Box: 307, Jimma, Ethiopia
}

\begin{abstract}
Coffee farming provides livelihoods for around 15 million farmers in Ethiopia and generates a quarter of the country's export earnings. Feedback from coffee farming communities, and observations on coffee production and coffee plant stress, indicate that climate change has already had a negative impact. Against a backdrop of rapidly increasing temperatures and decreasing rainfall, there is an urgent need to understand the influence of climate change on coffee production. Data Acquisition method obtained monthly surface minimum and maximum air temperature and the sum of rainfall output from in the CMIP archive, four scenarios (SSP1- 2.6, SSP2-4.5, SSP3-7.0 and SSP5-8.5) were used from 2001 to 2020 and for future outlook from 2021 to 2040 to assess the exposure of coffee farming to future climatic change. Results suggest that Ethiopia will likely experience increasing temperatures, but changes in rainfall are uncertain. The increasing temperatures will probably be accompanied by mild thermal stress for coffee during the dry seasons or drought. It could be concluded that coffee in the coming decades will probably experience mild thermal stress during the dry seasons, expressed by slight increases in physiological responses, but will probably remain within the normal margins. Timely, precise, science-based decision making is required now and over the coming decades, to ensure sustainability and resilience for the Ethiopian coffee sector.
\end{abstract}

Keywords: Temperature; Rain fall; Coffee

DOI: $10.7176 / \mathrm{JAAS} / 74-03$

Publication date:July $31^{\text {st }} 2021$

\section{Introduction}

Arabica coffee (Coffea arabica L.) provides Ethiopia with its most important agricultural commodity, contributing around one quarter of its total export earnings (EDRI/IFPRI, 2014). In 2015/16, Ethiopia exported around 180,000 metric tonnes of coffee at a value in excess of 800 million USD, making it Africa's largest coffee producer and the world's fifth largest coffee exporter (ICO, 2016), despite the fact that around half of the coffee produced each year is consumed in the country (USAID, 2010). In Ethiopia, coffee is produced within specific agro-ecological zones, over numerous geographical and political boundaries. At least $80 \%$ of Ethiopia's coffee comes from forests, forest-like habitats, or farms with shade (canopy) cover, representing land coverage of around $19,000 \mathrm{~km}^{2}$ with around another $4,000 \mathrm{~km}^{2}$ (c. 20\%) grown in small plots in partial shade or full sun. Most of the coffee is grown in areas that are covered, or were previously covered (Hailu et al., 2015) with humid evergreen forest: Moist Afromontane Forest (MAF) and Transitional Rain Forest (TRF) (Friis, 2010). MAF and TRF are found at $650-2,600 \mathrm{~m}$ (450-3,000 masl including extremes), although coffee is mostly confined to $1,200-2,200 \mathrm{~m}$. Coffee farming is also undertaken in association with a drier type of vegetation, classified as Dry Afromontane Forest, such as that found in the Harar Zone. The main coffee-growing areas of Ethiopia are found within the south-west and south-east (Oromia Region and Southern Nations, Nationalities and Peoples' Region), with modest and minor production in the north (Amhara Region and Benishangul-Gumuz Region, respectively) (Friis, 2010) (Fig. 1).

The future of coffee in Ethiopia will be affected by substantial changes in the environment, although not uniformly across the country. Changes in climate are adversely affecting coffee. Coffee farmers and other coffee sector stakeholders in Ethiopia report that coffee production has been negatively influenced by changes in climate. These changes include: an increase in the uncertainty of yearly weather patterns, particularly in precipitation variability and timing of the wet season; an extension of the dry season (shortening of the wet season); a more extreme (drier and hotter) end to the main dry season; more intense (extreme) weather (heavier rain, hotter days); and warmer nights (Dudu, 2012). Historical climate data shows that the mean annual temperature of Ethiopia has increased by $1.3{ }^{\circ} \mathrm{C}$ between 1960 and 2006, at an average rate of $0.28{ }^{\circ} \mathrm{C}$ per decade (McSweeney et al., 2010) and by $0.3{ }^{\circ} \mathrm{C}$ per decade in the south-west (Jury, M. R. \& Funk, C. 2013) and Amhara in the north (Jury, M. R. \& Funk, C. 2013). These temperature increases have been most rapid in the main wet season (July to September) at a rate of $0.32{ }^{\circ} \mathrm{C}$ per decade (McSweeney et al., 2010). Analyses of extreme temperature changes in various coffee-growing areas indicate positive trends for maximum temperature, warm days, warm nights and warm spell duration; and negative trends for cool days, cool nights, and cold spell duration across different eco/agricultural environments (pastoral, agro-pastoral and highland), although some of the trends are not statistically significant (Mekasha et al., 2014). The strong variability within Ethiopia's annual and decadal rainfall makes it difficult to detect long-term, country-wide trends (Williams, A. P. \& Funk C.A. 
2011). Despite these limitations, studies show: that February to May (Rowell et al., 2015)and June to September rains have declined (S eleshi, Y. \& Camberlin, P. 2006); a 15-20\% reduction in rainfall since the mid-1970s and late 2000s in southern, south-western and southeastern Ethiopia, particularly in the period of the initial early (February to March) rains in the south-east and east (Funk, C. et al., 2005) with an increase in drought frequency in all parts of Ethiopia during the last 10-15 years (Viste et al., 2013) ; a decrease in June to September precipitation in the Greater Horn of Africa by approximately 1 s.d. during the period 1950-1989, corresponding to decreases of over $30 \mathrm{~mm}$ per decade throughout much of the Ethiopian Highlands20; and a downward trend in rainfall of $0.4 \mathrm{~mm}$ per month per year over the southwestern region in the period 1948-2006 (Jury, M. R. \& Funk, C. 2013).

It is imperative to better understand the influence of climate change on coffee farming in Ethiopia, given the importance of coffee production and consumption for this country. The impacts of observed and projected changes in climate on coffee farming in Ethiopia are largely unknown. The only available climate change study for Ethiopian coffee is for native populations of Arabica coffee, using a single species distribution model (SDM), forest-only data and one GCM25. To see the objective Climate Analogue Mapping for coffee production in Ethiopia.

\section{Methodology}

\subsection{Study area map, description}

The coffee zones represented by coloured polygons: red/pink, North Zone (coffee areas: Amhara and Benishangul Gumuz); light blue, South West Zone (coffee areas: Wellega, Illubabor, Jimma-Limu, Kaffa, Tepi and Bench Maji); light green, Rift Zone (coffee areas: Rift North and Rift South); dark blue, South East Zone (coffee areas: Sidamo, Yirgacheffe, Bale and Central Eastern Highlands); dark green, Harar Zone (coffee areas: Arsi, West Hararge and East Hararge). Ethiopia is the birthplace of coffee and has some of the most dynamic flavors you'll find anywhere in the world. The country is located Between 3 to $15^{0} \mathrm{~N}$ and 33 to $48^{0} \mathrm{E}$. There are between 6 and 10 thousand different types of coffee from Ethiopia, but they are usually distinguished by their region, altitude, and cupping score instead of by type. The coffee plants that grow indigenously are known as heirloom varieties due to their rich history of growing in a near-perfect natural environment, that seems almost built to grow coffee (Fig. 1).

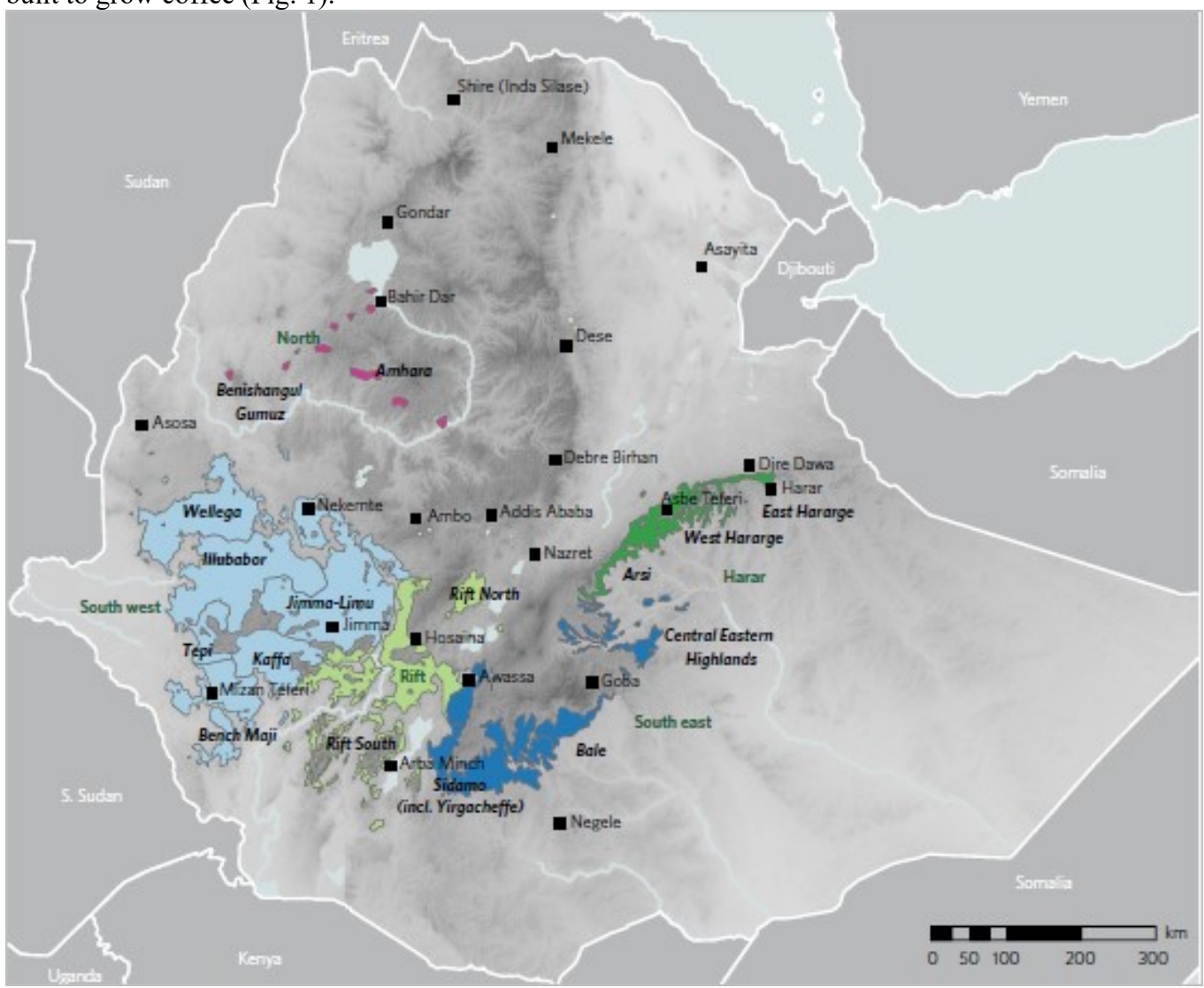

Figure 1| the main coffee growing zones and areas of Ethiopia. 


\subsection{Data Acquisition and analysis method}

The outlooks of data are the rainfall and temperature retrieved from the Netherlands's meteorological institution (KNMI):https://climexp.knmi.nl/start.cgi, as the following data Acquisition method obtained monthly surface minimum and maximum air temperature and the sum of rainfall output from in the CMIP archive, four scenarios (SSP1- 2.6, SSP2-4.5, SSP3-7.0 and SSP5-8.5) were used for future outlook from 2001 to 2020 and from 2021 to 2040 (Fig.2). The latitude and longitude of the country was used to download site specific data. Data were reorganized (Csv comma delimited) in a way it fits the requirements of $\mathrm{R}$ software. Data were imported to $\mathrm{R}$ studio from excel sheet analyzed using $\mathrm{R}$ software and package modified and used to predict future and past changes.

\section{Select a monthly field \\ CMIP6 scenario runs \\ First batch of CMIP6 runs downlaoded November 2019, will be updated shortly. \\ Global mean temperatures can be analysed or downloaded separately.}

\begin{tabular}{|c|c|c|c|c|c|c|}
\hline Select field & \multicolumn{6}{|c|}{ Choose a field and press this button } \\
\hline \multicolumn{7}{|l|}{ Surface variables } \\
\hline model & $\exp$ & tas & $\begin{array}{l}\text { tas } \\
\text { min }\end{array}$ & $\begin{array}{l}\text { tas } \\
\text { max }\end{array}$ & pr & psl \\
\hline \multirow[t]{4}{*}{ one member per model } & ssp126 & $\mathrm{O}_{13}$ & $\mathrm{O}_{8}$ & $\mathrm{O}_{8}$ & $O_{11}$ & $O_{13}$ \\
\hline & ssp245 & $\mathrm{O}_{13}$ & $\mathrm{O}_{8}$ & $\mathrm{O}_{8}$ & $O_{11}$ & $\mathrm{O}_{13}$ \\
\hline & 5sp370 & $O_{13}$ & $\mathrm{O}_{8}$ & $O_{8}$ & $O_{11}$ & $O_{13}$ \\
\hline & ssp585 & $O_{13}$ & $\mathrm{O}_{8}$ & $O_{8}$ & $O_{11}$ & $O_{13}$ \\
\hline \multirow[t]{3}{*}{ all members } & ssp126 & $\mathrm{O}_{68}$ & $\mathrm{O}_{61}$ & $O_{61}$ & $\mathrm{O}_{66}$ & $\mathrm{O}_{68}$ \\
\hline & ssp245 & $\mathrm{O}_{68}$ & $\mathrm{O}_{61}$ & $\mathrm{O}_{61}$ & O66 & O68 \\
\hline & ssp370 & $\mathrm{O}_{68}$ & $\mathrm{O}_{61}$ & $\mathrm{O}_{61}$ & O66 & $\mathrm{O}_{68}$ \\
\hline
\end{tabular}

Figure 2; Data acquisition method

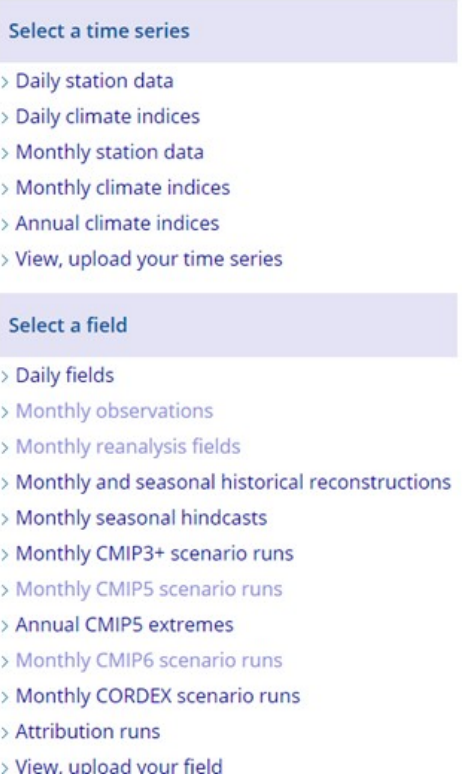

View. unload vour field

\section{Results}

Temperatures vary according to locality, altitude, season and physical features of the landscape. Historical data for Ethiopia provides specific details of the general warming trend. Our data showed that the mean annual temperature has increased by $1.3^{\circ} \mathrm{C}$ between 2001 and 2020 , at an average rate of $0.28^{\circ} \mathrm{C}$ per decade (Fig. 3) under all scenarios. Observations also show significantly increasing trends in the frequency of hot days, and much larger increasing trends in the frequency of hot nights; the frequency of cold days has decreased significantly in all seasons.

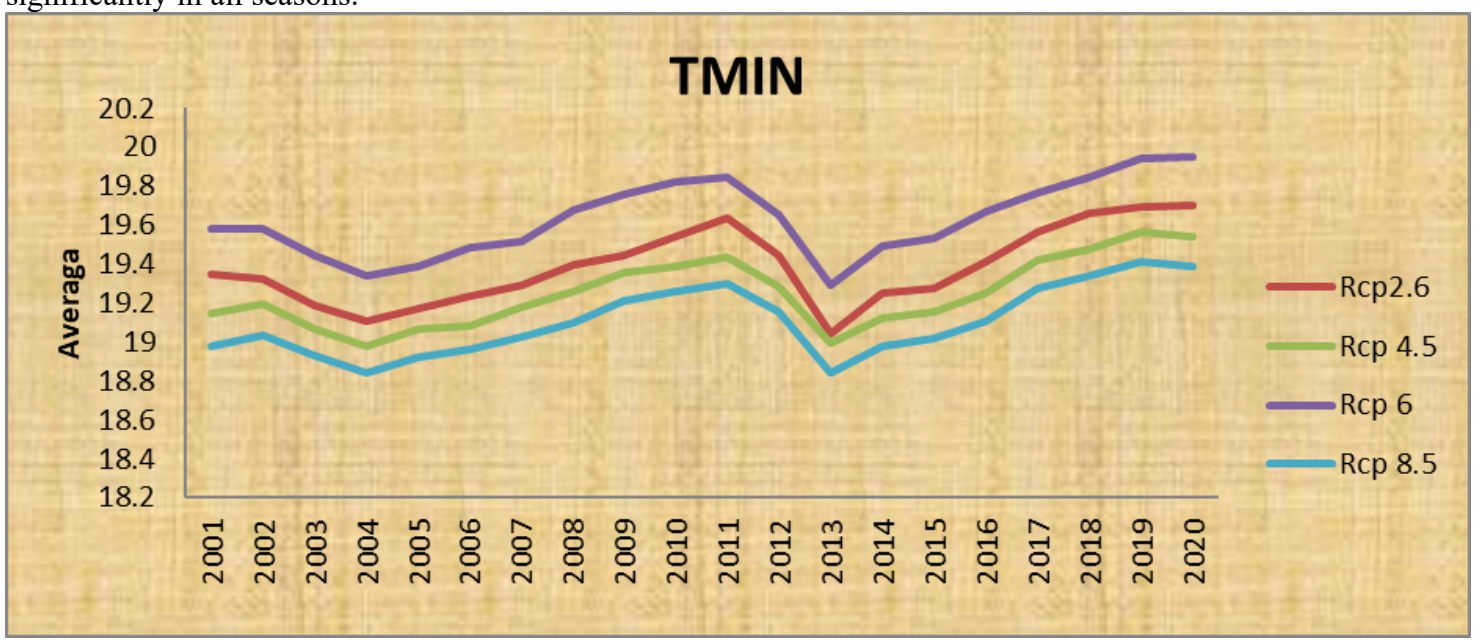

Figure 3: Mean minimum temperature for 2001 to 2020 period. 
Table 1: Slope of minimumTemperture for Ethiopia 2001 to 2020

\begin{tabular}{|l|l|l|}
\hline & Senarios & $\mathrm{R}$ slope \\
\hline & RCP22.6 & $\begin{array}{l}\mathrm{y}=0.0196 \mathrm{x}+19.423 \\
\mathrm{R}^{2}=0.3497\end{array}$ \\
\hline & RCP4.5 & $\begin{array}{l}\mathrm{y}=0.0204 \mathrm{x}+19.17 \\
\mathrm{R}^{2}=0.3722\end{array}$ \\
\hline & RCP6 & $\begin{array}{l}\mathrm{y}=0.02 \mathrm{x}+19.038 \\
\mathrm{R}^{2}=0.4347\end{array}$ \\
\hline & RCP8.5 & $\begin{array}{l}\mathrm{y}=0.02 \mathrm{x}+18.892 \\
\mathrm{R}^{2}=0.4414\end{array}$ \\
\hline
\end{tabular}

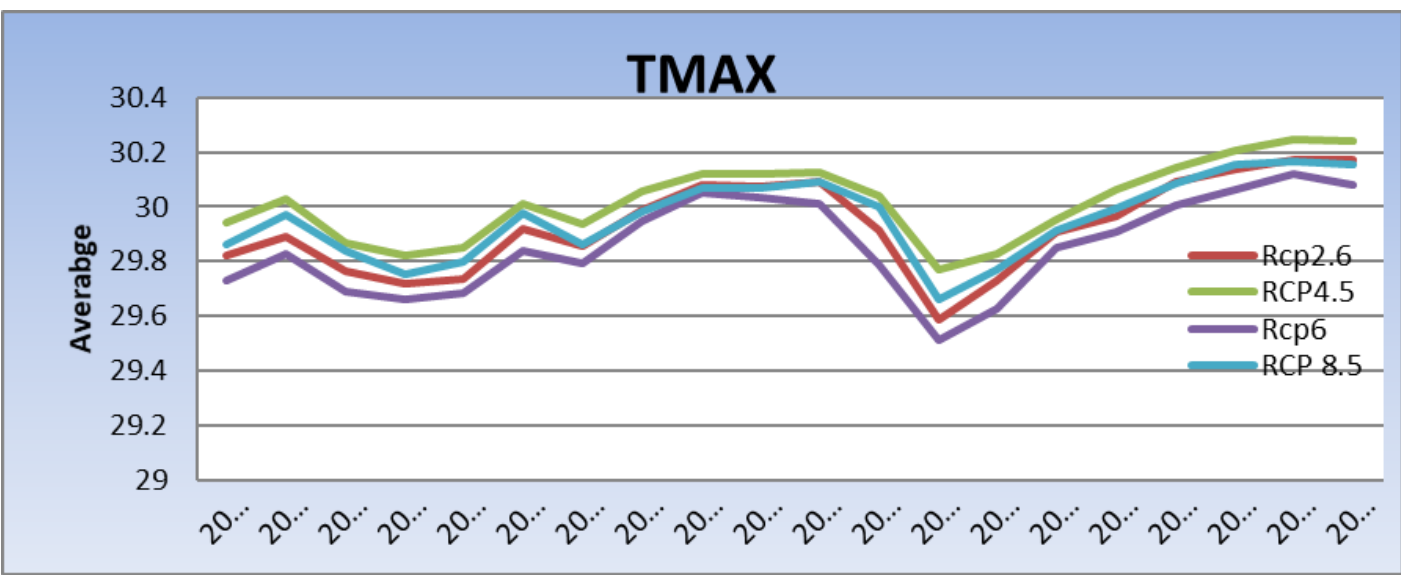

Figure 4: Mean maximum temperature for period 2001 to 2020.

Table 2: Slope of maximum Temperture for Ethiopia 2001 to 2020

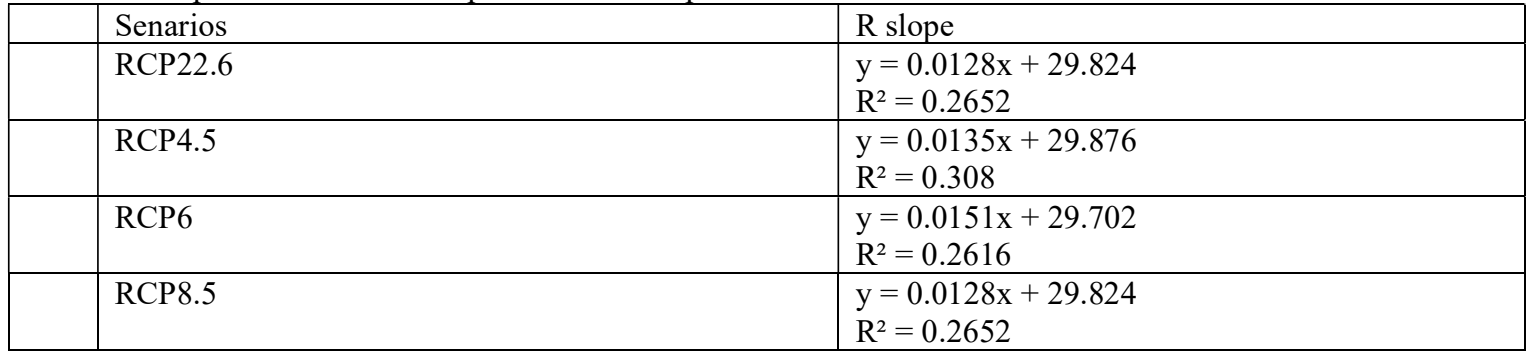

\subsection{Rainfall (precipitation)}

Rainfall is the most important factor governing the distribution of coffee farming and wild coffee forests in Ethiopia[8]. The distribution of rainfall varies greatly across Ethiopia. Clear annual patterns are evident, although rainfall is extremely variable (Fig 7). The strong variability within Ethiopia's annual and decadal rainfall makes it difficult to detect long term trends, and that there is no statistically significant trend in observed mean rainfall in any season for which climate data is available (2001-2020) (Fig.\&). 


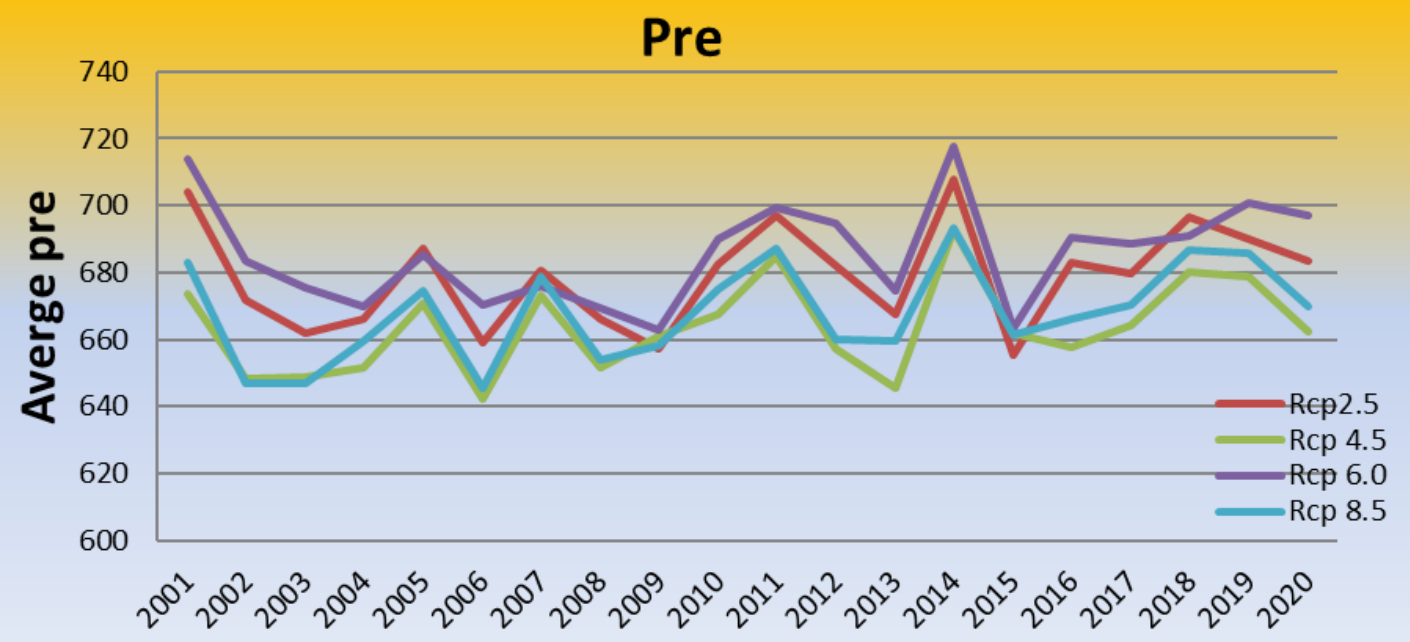

Figure 5: Mean annual precipitation for the period of 2001 to 2020 in Ethiopia

Table 3; Slope of annual presipition for Ethiopia 2001 to 2020

\begin{tabular}{|l|l|l|}
\hline Senarios & $\mathrm{R}$ slope \\
\hline & RCP22.6 & $\begin{array}{l}\mathrm{y}=0.0154 \mathrm{x}+20.308 \\
\mathrm{R}^{2}=0.8448\end{array}$ \\
\hline & RCP4.5 & $\begin{array}{l}\mathrm{y}=0.0281 \mathrm{x}+20.162 \\
\mathrm{R}^{2}=0.9575\end{array}$ \\
\hline & RCP6 & $\begin{array}{l}\mathrm{y}=0.0196 \mathrm{x}+20.513 \\
\mathrm{R}^{2}=0.8945\end{array}$ \\
\hline & RCP8.5 & $\begin{array}{l}\mathrm{y}=0.0413 \mathrm{x}+20.04 \\
\mathrm{R}^{2}=0.9689\end{array}$ \\
\hline
\end{tabular}

\subsection{Predicted future change}

\subsubsection{Temperature}

Warming projections under a low emissions RCP (RCP 2.6) indicate that the country will see a change of around $0.5^{\circ} \mathrm{C}$ (and less than $1^{\circ} \mathrm{C}$ ) by the end of $2030 \mathrm{~s}$, relative to the late $2010 \mathrm{~s}$ mean annual temperature baseline (Fig. 5 \& 6). Under a high emissions RCP (RCP 8.5) an increase of more than $1^{\circ} \mathrm{C}$ could occur by the 2030 s across much of Ethiopia. It is likely that land temperatures over the country will rise faster than the global land average, particularly in the more arid regions, and that the rate of increase in minimum temperatures will exceed that of maximum temperatures, which could cause a higher frequency of heat waves as well as higher rates of evapotranspiration(Fig.5 \& 6).

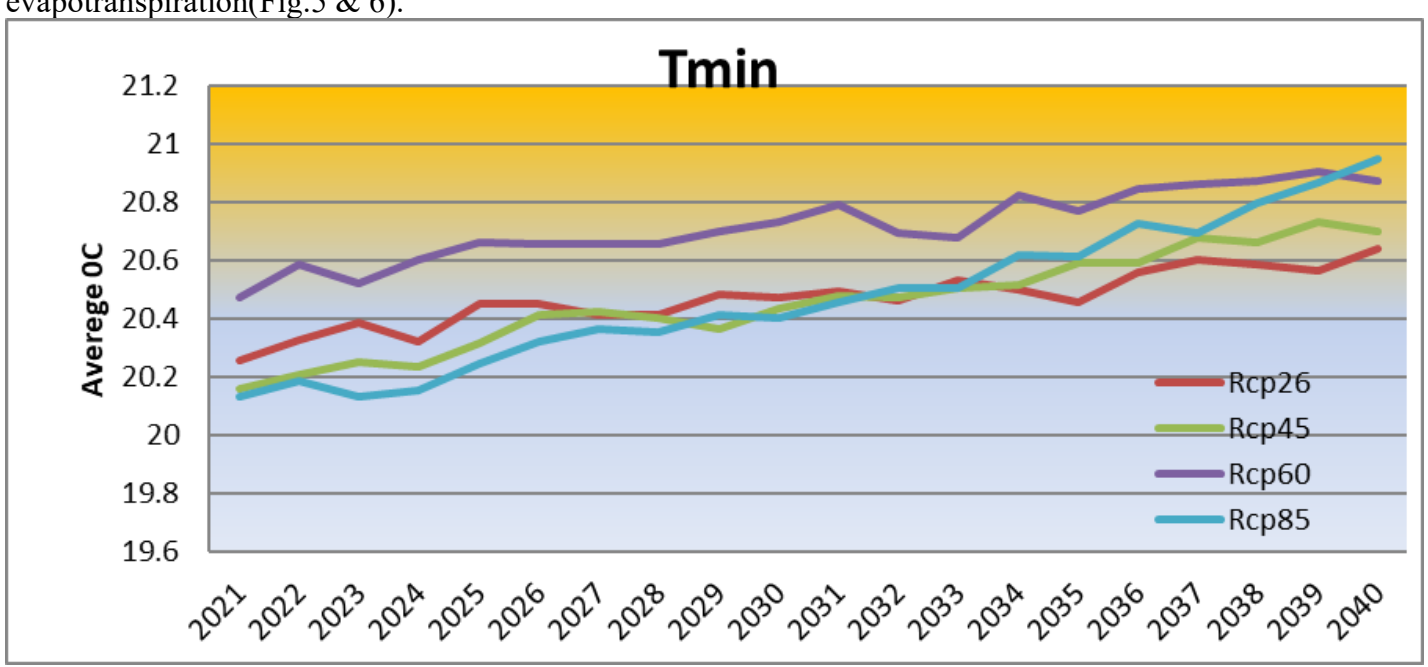

Figure 6: Mean minimum temperature for period 2021 to 2040. 
Table 4: Slope of minimum Temperture for Ethiopia 2021 to 2040

\begin{tabular}{|c|c|}
\hline Senarios & R slope \\
\hline RCP22.6 & $\begin{array}{l}\mathrm{y}=0.0143 \mathrm{x}+30.708 \\
\mathrm{R}^{2}=0.8544\end{array}$ \\
\hline RCP4.5 & $\begin{array}{l}\mathrm{y}=0.0229 \mathrm{x}+30.861 \\
\mathrm{R}^{2}=0.9487\end{array}$ \\
\hline RCP6 & $\begin{array}{l}\mathrm{y}=0.0169 \mathrm{x}+30.695 \\
\mathrm{R}^{2}=0.7892\end{array}$ \\
\hline RCP8.5 & $\begin{array}{l}\mathrm{y}=0.0169 \mathrm{x}+30.695 \\
\mathrm{R}^{2}=0.7892\end{array}$ \\
\hline
\end{tabular}

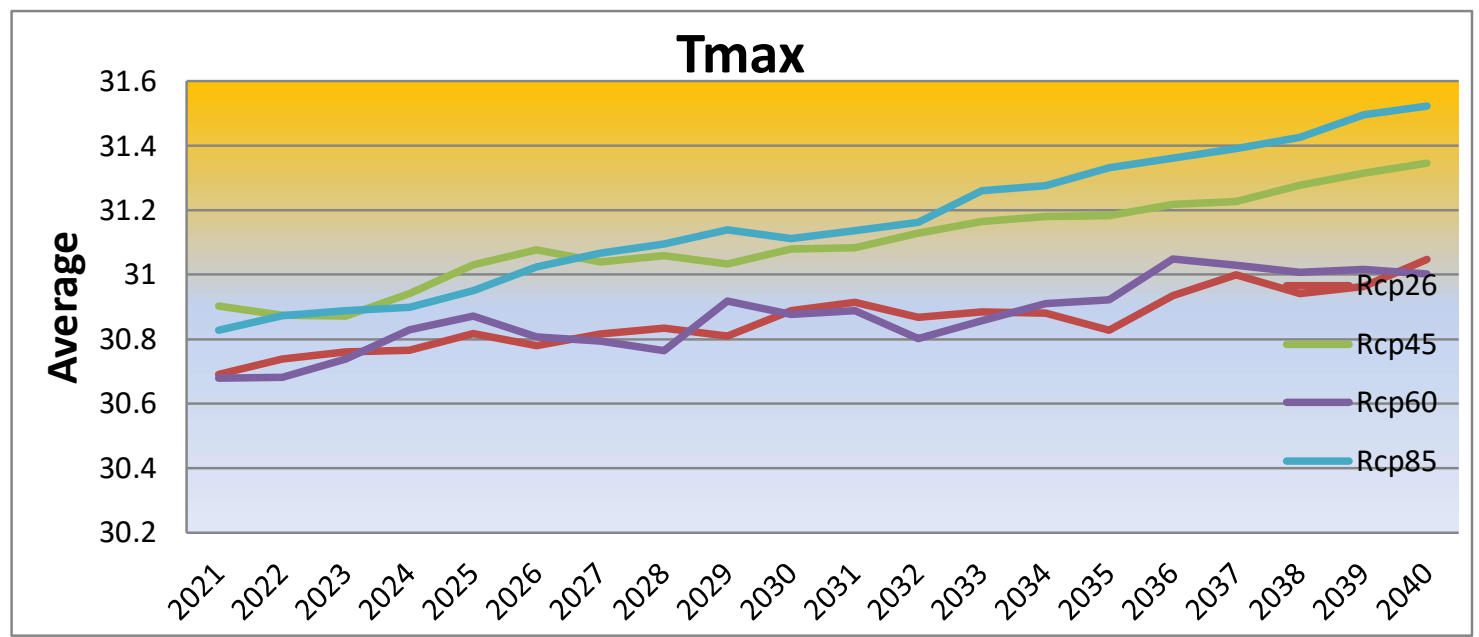

Figure 7; maximum temperature for period 2021 to 2040.

Table 5; Slope of maximum Temperture for Ethiopia 2021 to 2040

\begin{tabular}{|l|l|l|}
\hline & Senarios & R slope \\
\hline & RCP22.6 & $\begin{array}{l}\mathrm{y}=0.6216 \mathrm{x}+672.43 \\
\mathrm{R}^{2}=0.0562\end{array}$ \\
\hline & RCP4.5 & $\begin{array}{l}\mathrm{y}=1.0141 \mathrm{x}+657.5 \\
\mathrm{R}^{2}=0.1694\end{array}$ \\
\hline & RCP6 & $\begin{array}{l}\mathrm{y}=0.6479 \mathrm{x}+678.88 \\
\mathrm{R}^{2}=0.0603\end{array}$ \\
\hline & RCP8.5 & $\mathrm{y}=1.0141 \mathrm{x}+657.5$ \\
& & $\mathrm{R}^{2}=0.1694$ \\
\hline
\end{tabular}

\subsection{Rainfall (precipitation)}

Rainfall change is projected increases of heavy precipitation over most of Ethiopia. However, regional climate model studies also suggest drying over most parts of the country(Fig.8). 


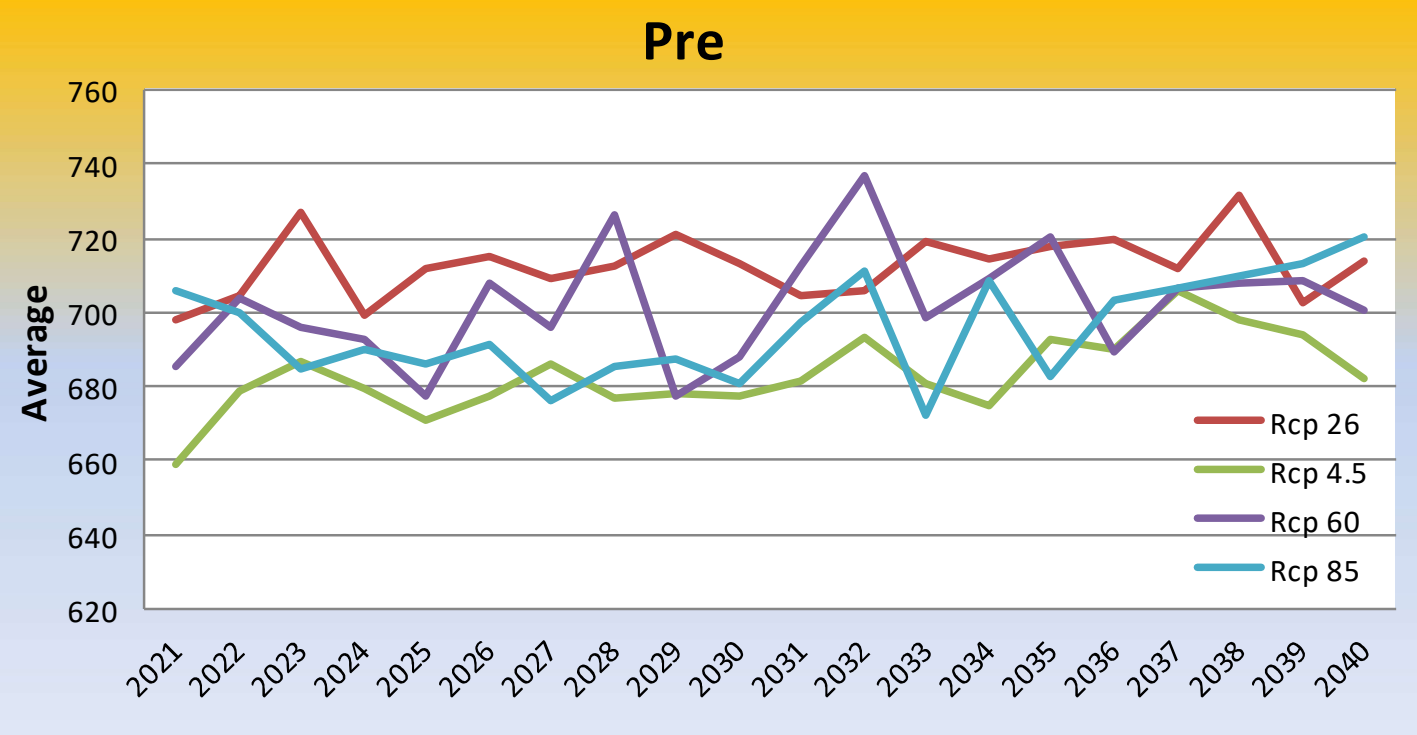

Figure 8: Mean annual precipitation for the period of 2021 to 2039 in Ethiopia

Table 6: Slope of presipition for Ethiopia 2021 to 40

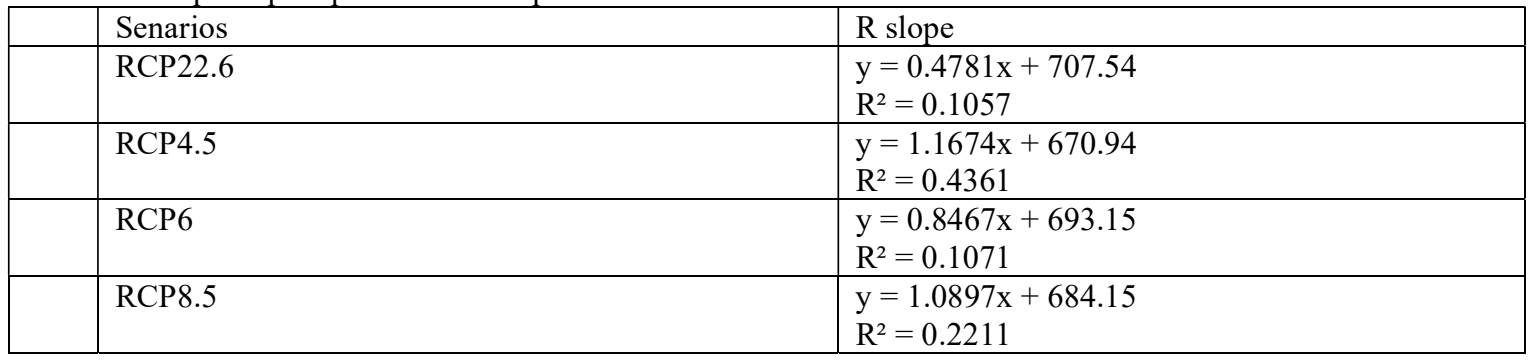

\section{Discussion}

Arabica coffee is a crop sensitive to climate changes, especially temperature extremes and drought. Climate projections provide useful estimates of potential future conditions, which we can use to explore the sensitivity of coffee production. All of the coffee zones indicated in Fig. 1 could be negatively influenced to some extent, particularly at lower altitudes. Across Ethiopia, the most climatically suitable part of the overall niche is projected to drastically decline in the long-term. Across the entirety of the coffee landscape, the temperature shows projected temperature increases of $1-2{ }^{\circ} \mathrm{C}$ under all scenarios from 2001-2020 to 2021-2040 (Figures 3, 4,6 \& 7). Temperature seasonality generally increases. Critically, the rainfall shows little change. Thus, the total rainfall for each area experienced in the present day is key to understanding future suitability, as any increases and decreases in rainfall are mostly projected to be negligible to slight ( Fig.5 \& 8).

In summary, the key influencing factors can be viewed as a relatively simple interaction between rainfall and temperature: coffee areas that start with low rainfall cannot tolerate an increase in temperature, especially as rainfall is not projected to change by any considerable amount; temperatures are projected to increase steadily and substantially. If Ethiopian rainfall declines continue, in contrast to the negligible changes in precipitation observed in our projections, they would further amplify the temperature-driven changes identified here. This is consistent with projections indicating that increases in potential evapotranspiration may reduce the effective length of the African growing seasons (Cook, K. H. \& Vizy, E. K) 44. Higher temperature leads to accelerated development and ripening, and eventually, loss of beverage quality. Excessive exposure to temperatures as high as $30^{\circ} \mathrm{C}$ leads to stress, and challenge survival of the plant itself (Franco 1958; cited in Davis et al. 2012). Similarly extreme low temperature is also lethal for the coffee plant.

However, the Ethiopian coffee production has great potential of resilience to the effects of climate change, due to (i) the diverse and adaptive management practices, (ii) presence of high genetic diversity of both wild and cultivated coffee, and (iii) vast highland plateau suitable for coffee. The management practices for coffee production involves growing coffee under deep, medium and no-shade. Most of the shade grown coffee system 
resembles natural forest in structural complexity and diversity. Shade modifies the micro-climate, and can moderate extreme temperature by at least $4^{0} \mathrm{C}$. Possessing over $99.7 \%$ of the coffee genetic resources (Kotecha 2008), Ethiopia also has a unique opportunity to select drought, disease, temperature extremes and other stresses resulting from climate change. The value of the genetic diversity can be witnessed from the tolerance of Ethiopian cultivated coffee to different diseases and pests that devastated coffee production other parts of the world, like coffee leaf rust, coffee berry disease, and coffee berry borer. A number of studies revealed that the forest coffee system supports high functional diversity in terms of disease tolerance and pest resistance (Adugna et al. 2005), and drought tolerance (Kufa 2006; Beining et al. 2005). These wild coffee genetic resources are important for both national and international coffee breeding programs that aim at increasing productivity, disease resistance and tolerance, low caffeine content and tolerance to drought, water logging and temperature extremes.

Over $50 \%$ of African highland areas above $1500 \mathrm{~m}$ are found in Ethiopia. The highlands also receive high rainfall. The country has the largest highland plateau suitable for coffee production. The Ethiopian Institute of Agricultural Research estimated that there are 4.48 million hecatares of highly suitable and 17.63 million hectares of moderately suitable areas for coffee production in Ethiopia. This gives ample space in which areas of coffee production can shift, in response of the negative effects of climate change.

\section{Summary and Conclusion}

A recent climate change impact prediction on indigenous Arabica coffee showed a profoundly negative trend for the future distribution under the influence of accelerated global climate change. Accordingly, the current predicted areas of distribution of indigenous Arabica coffee in Ethiopia can be reduced. Timely, precise, sciencebased decision making is required now and over the coming decades, to ensure sustainability and resilience for the Ethiopian coffee sector. Significant intervention would be required, including the planting of shade cover or the restoration of humid forest cover for areas with little or no present-day forest cover. A concerted effort would be needed to identify and establish new coffee areas at higher altitudes, with particular attention placed on competing land-use issues. Shifts could also occur without major intervention, as farmers realize the potential for growing coffee in their upland areas and locations in the North Zone are already being developed as new coffee areas not previously seen for coffee farming in Ethiopia, indicating that assisted migration is already underway.

Resilience built via the migration of coffee farms could be supplemented with (location- and time-specific) improvements in coffee productivity (kg per hectare; for example, by increasing soil fertility and pruning) and quality ( $\mathrm{kg}$ per \$; for example, better harvesting and post-harvest processing), in order to offset unit area reductions in environmental suitability. In addition, there is scope for investing in locally appropriate, cost effective agronomy adaptations (such as mulching, irrigation, improved shade management and terracing). Irrigation would provide the single most effective adaptation measure, especially where implementation costs are low, for example, the diversion of nearby streams and rivers. Our projections would serve to provide a framework for the likely success, timing, duration and location of interventions.

Wild coffee forests. Ethiopia's wild coffee forests have considerable fundamental value as the main storehouse of C. arabica (Arabica coffee) genetic resources, with specific benefits for the coffee sector, locally, regionally and globally. Most directly, indigenous Arabica coffee plays a key role in Ethiopian coffee production as an important source of planting material for farms via seed and seedlings. Protection of these resources should thus be seen as a key part of a resilience strategy.

\section{Recommendations /Key adaptation measures}

Air and soil temperature and moisture can be altered by specific farming interventions, and provide a buffer against inadequate growing conditions and extreme weather events. The most obvious interventions are irrigation, shade management and mulching, but terracing has clear benefits, and pruning is also advocated in some cases. Observations of on-farm adaptation and improvements in coffee farming practices across Ethiopia indicate the potential to provide various levels of resilience for many (but not all) farmers. Careful assessment of each farming site is required to see which interventions, or combination of measures, would be most suitable. Improved cultivars and selections of indigenous Arabica coffee may provide some potential, especially for disease resilience and improved productivity, but significant climate resilience is unlikely based on field observations of field trials, and available genetic diversity information.

Irrigation: The use of extra water to boost and/or maintain soil water availability for coffee plants is an ancient and highly effective means of improving yield and quality. If irrigation practices are good, Arabica coffee can be successfully grown in places that would otherwise be unsuitable due to low rainfall. There are numerous examples in Ethiopia where good to excellent coffee is grown with low-cost irrigation systems (Amhara region).

Tree shade management: Effective shade management can improve coffee growing conditions by reducing daytime air and soil temperatures, and increasing humidity and soil moisture. The difference in daytime temperatures between shaded and unshaded coffee plots can be around $4^{\circ} \mathrm{C}$. Choice of shade tree species, 
planting density and canopy coverage are key factors in good shade management. Effective shade management can also counter the negative effects of heavy rain (e.g. run-off prevention, and coffee flower protection from heavy raindrops) and drying winds.

Mulching: Covering the soil with different materials (e.g. compost, manure) not only helps to preserve soil moisture and decrease soil temperature (reducing evapotranspiration), but it can also increase soil fertility, supress weeds, and improve rainfall penetration into the ground.

\section{References}

Davis, A. P., Gole, T. W., Baena, S. \& Moat, J. The impact of climate change on natural populations of Arabica coffee: predicting future trends and identifying priorities. PLoS ONE 7, e47981 (2012).

Dudu, V. P. Impacts of Climate Change on Coffee Farming in Ethiopia (LAP Lambert Academic, 2012).

Friis, I., Demissew, S. \& Breugel, P. V. Atlas of the potential vegetation of Ethiopia. Biol. Skrif. 58, 1-307 (2010).

Funk, C. et al. Recent Drought Tendencies in Ethiopia and Equatorial Subtropical Eastern Africa (FEWS NET, 2005).

. Hailu, B., Maeda, E. E., Heiskanen, J. \& Pellikka, P. Reconstructing preagricultural expansion vegetation cover of Ethiopia. Appl. Geogr. 62, 357-365 (2015).

Jury, M. R. \& Funk, C. Climatic trends over Ethiopia: regional signals and drivers. Int. J. Climatol. 33, 1924 1935 (2013).

Mekasha, A., Tesfaye, K. \& Duncan, J. Trends in daily observed temperature and precipitation over three Ethiopian eco-environments. Int. J. Climatol. 34, 1990-1999 (2014).

McSweeney, C., New, M. \& Lizcano, G. UNDP Climate Change Country Profiles: Ethiopia (UNDP, 2010); http://www.geog.ox.ac.uk/research/climate/projects/undp$\mathrm{cp} /$ UNDP_reports/Ethiopia/Ethiopia.hires.report.pdf

Rowell, D. P., Booth, B. B. B., Nicholson, S. E. \& Good, P. Reconciling past and future rainfall trends over east Africa. J. Climate 28, 9768-9788 (2015).

Seleshi, Y. \& Camberlin, P. Recent changes in dry spell and extreme rainfall events in Ethiopia. Theor. Appl. Climatol. 83, 181-191 (2006).

Viste, E., Korecha, D. \& Sorteberg, A. Recent drought and precipitation tendencies in Ethiopia. Theor. Appl. Climatol. 112, 535-551 (2013).

Williams, A. P. et al. Recent summer precipitation trends in the greater horn of Africa and the emerging role of Indian ocean sea surface temperature. Clim. Dynam. 39, 2307-2328 (2012). 